\title{
Mathematical Creative Process Wallas Model in Students Problem Posing with Lesson Study Approach
}

\begin{tabular}{|c|c|c|c|c|}
\hline $\begin{array}{l}\text { Muhammad 'Azmi Nuha } \\
\text { Post-graduate School of } \\
\text { azminuha@gmail.com }\end{array}$ & Universtitas & Negeri & Semarang, & Indonesia, \\
\hline $\begin{array}{l}\text { S. B. Waluya } \\
\text { Post-graduate School of } \\
\text { s.b.waluya@mail.unnes.ac.id }\end{array}$ & Universitas & Negeri & Semarang, & Indonesia, \\
\hline $\begin{array}{l}\text { Iwan Junaedi } \\
\text { Post-graduate School of } \\
\text { iwanjunmat@mail.unnes.ac.id }\end{array}$ & Universitas & Negeri & Semarang, & Indonesia, \\
\hline
\end{tabular}

Creative thinking is very important in the modern era so that it should be improved by doing efforts such as making a lesson that train students to pose their own problems. The purposes of this research are (1) to give an initial description of students about mathematical creative thinking level in Problem Posing Model with Lesson Study approach in Digital Class, (2) to describe the teaching quality of Problem Posing Model with Lesson Study approach in Digital Class toward students' mathematical creative thinking, and (3) to find the pattern of students' mathematical creative thinking process of Wallas Model in Problem Posing Model with Lesson Study in Digital Class at every creative thinking level. This research used mixed method design. Validation, observation, and test were used to collect the data of teaching quality. The results show that (1) an initial description of students' mathematical creative thinking level (CTL) was in the range of CTL 4 to CTL 1, (2) Problem Posing Model with Lesson Study approach in Digital Class had quality to improve creative thinking, and (3) the patterns of students' mathematical creative thinking at every stage of Wallas Model are various according to their own creative thinking level.

Keywords: creative thinking, lesson study, problem posing, Wallas creative process, Wallas Model, mathematical creative process

\section{INTRODUCTION}

The existence of ASEAN Economic Community (AEC) requires people to have quality of human resources. People with high quality of human resources and expertise are able 
to work together, perform high level of thinking skill, be creative, have skill, understand various cultures, and be communicative and have long life learning for facing global competition. Arnyana (2006) explained that to solve the problem, we need an intellectual modal, especially higher order thinking in order to become a good worker. Therefore, creative thinking becomes very important to be given to someone since his early age. This can be realized by giving creative learning in the students' mathematics class.

Problem solving is a way used by Silver (1997) to develop students' mathematical creativity. Siswono (2010) viewed mathematical creative thinking as a combination of logical and divergent thinking in intuition but still consciousness. When a person applies creative thinking to solve a problem, divergent thinking will generate ideas or new ideas. Thinking logically involves rational and systematic process to examine and validate conclusions. Meanwhile, thinking divergently is considered as thinking ability to find ideas to solve the problem.

Lestari (2015) described problem posing as teaching model in which the students are asked to pose a problem based on certain situation. Silver (1997) explained that students cannot only be fluent in generating many problems from a situation but they can also develop flexibility with generating many solutions in the problem. In addition, students can also develop ability in generating new solution through that way.

Efforts to improve creative thinking should be done through teaching in the classroom. Astra, Umiatin, and Jannah (2012) described problem posing model as teaching model that requires students to pose their own problems then solve them independently. This is relevant with the opinion from Zevenbergen, Dole, and Wright (2004) which explained that problem posing was a teaching model that emphasizes students to pose their own problems. These strategies can provide benefits for students to involve their mathematical ideas. Problem posing model can give an overview of students' mathematical creative process in posing problem.

Purnomo, Kartono, and Widowati (2015) had developed teaching tools using problem posing model. The results of this study stated that the teaching tools using problem posing model achieve criteria of valid, practical, and effective toward mathematics teaching. It showed that the problem posing model was right used in mathematics teaching. In addition, problem posing model could provide an overview of the students' mathematical creative process when posing a problem.

According to Siswono (2004), creative process was a combination process of thinking logically and divergently. Thinking divergently refers to a person ability to find ideas to solve problems while thinking logically is person's ability to verify these ideas into a creative solution. Wallas describes four stages of creative process including preparation, incubation, illumination, and verification (Siswono, 2004; Warr \& O'Neill, 2005).

At preparation stage, students will prepare himself to solve the problem by clarifying the problem, collecting relevant data then reviewing it, and looking for ways to solve the problem. Furthermore, at incubation stage, students will be free from the problem. This stage is the beginning process to inflict inspiration which is the starting point of new invention or creation from pre-conscious area. At illumination stage, students get 
solution followed by inspiration and ideas that start and make a new inspiration and idea. In the last stage which is the verification stage, students test and examine solution on reality.

Efforts to improve creative thinking should be accompanied by efforts to improve teaching quality. Improving teaching quality can be done through Lesson Study Approach. Lesson Study is an educational program in Japan to improve teaching quality in the classroom. Stage of Lesson Study were plan, do, and see (Takahashi \& Yoshida, 2004; Lenski \& Caskey, 2009, Fernandez, 2002; Doig \& Groves, 2011; Mahmudi, 2009). The three stages were used to achieve quality in teaching. Plan and do stages have roles for teacher to create valid teaching tools. After teaching tool was valid then it can be continued with doing good teaching in the classroom. In do stage, teacher taught in the classroom with observed by the observer so teaching implementation would be controlled well.

All countries wanted to integrate technology for teaching in the classroom to improve teaching quality. Indonesia was also trying to develop the application of technology through teaching in the classroom; it was one of the 2013 Curriculum standard process. The results of interviews with the chief of Mathematics Teacher Communities in Semarang stated that Semarang would apply digital class that would be tested at certain schools in Semarang. The program was a program that was relevant with the 2013 Curriculum standard contents.

Based on the description, the purposes of this research are 1) to give an initial description of students' mathematical creative thinking in teaching of Problem Posing Model with Lesson Study Approach in Digital Class, (2) to describe teaching quality of Problem Posing Model with Lesson Study Approach in Digital Class toward students' mathematical creative thinking, and (3) to find the pattern of mathematical creative process of Wallas Model of students in Digital Class with Problem Posing Model with Lesson Study Approach at every creative thinking level.

\section{METHOD}

\section{Research Model}

Research method used in this research was mixed methods by using concurrent embedded strategy. Creswell (2009) explained that concurrent embedded strategy was a mixed method strategy that applies quantitative and qualitative data collection phases at the same time.

\section{Populations and Samples}

Population in this quantitative research was all students of eighth graders in State Junior High School 30 of Semarang academic year 2016/2017. The samples of quantitative research were 2 of 9 classes that exist in eight-grade class. One class was selected as the experimental class and the other class was selected as the control class. 8C class was selected as the experimental class and $8 \mathrm{D}$ class was selected as the control class. Qualitative research subjects were taken from the experimental class. In the experimental class, students are classified by creative thinking level. Every level of creative thinking was taken 2 students to be qulaitative research subjects to find students creative process of the research subjects. 


\section{Data Collection Tools}

Data of initial ability of mathematical creative thinking were taken by giving initial test of mathematical creative thinking in experimental class. The data were used to choose qualitative research subjects.

The data of teaching quality at the preparation stage were collected by validating lesson plans and the mathematical creative thinking tests that had been developed by researcher. The validators in this research were 2 lecturers of Mathematics Education Master Degree Program of Universitas Negeri Semarang and 1 teacher of State Junior High School 30 of Semarang. At the implementation stage, the researcher carried out observation of teaching and gave questionnaires to students of the experimental class. At the evaluation stage, the researcher tested the effectiveness of teaching.

The data of mathematical creative processes is taken using observation, interview, and documentation. Observation data is taken when students are working on the students' worksheets. Two observers focused their observations on the research subjects chosen during the four teaching meetings. Observation sheet was prepared to collect the data of mathematical creative process of the research subjects. Data collected from observations were words that described mathematical creative process of research subjects.

After making observations on the four meetings then the researcher conducted an interview on the research subjects. Interviews were used to collect deeper information that had not been discovered during observations or to confirm the findings in observational data. In addition, interviews are also part of triangulation to compare with observation data for validating data. Documentation of the students' work were taken when they were working on students' worksheet and recording video of interviews with research subjects.

\section{Data Analysis}

Data of initial ability of mathematical creative thinking were classified based on creative thinking level. Siswono in Khumaidi (2013) classified the level of students' creative thinking based on the achievement indicators of fluency, flexibility and novelty consisting of five levels: (Creative Thinking Level) CTL 4 (Very Creative), CTL 3 (Creative), CTL 2 (Creative Enough), CTL 1 (Less Creative), and CTL 0 (Not Creative). Criteria for mathematical creative thinking level according to Table 1.

Table 1

Characteristics of Students Creative Thinking Level

\begin{tabular}{llll}
\hline Creative Thinking Level & fluency & flexibility & novelty \\
\hline CTL 4 & $\sqrt{ }$ & $\sqrt{ }$ & $\sqrt{ }$ \\
\hline CTL 3 & $\sqrt{ }$ & - & $\sqrt{ }$ \\
& $\sqrt{ }$ & $\sqrt{ }$ & - \\
\hline CTL 2 & - & $\sqrt{ }$ & $\sqrt{ }$ \\
& - & - & $\sqrt{ }$ \\
& - & $\sqrt{ }$ & - \\
\hline CTL 1 & $\sqrt{ }$ & - & - \\
\hline CTL 0 & - & - & - \\
\hline
\end{tabular}


The data on planning stage were validation data of lesson plan and mathematical Creative Thinking Test. Three validators carried out the validation of lesson plan and Mathematical Creative Thinking Test. The average validation score of the three validators were converted according to Table 2 .

Tabel 2

Teaching Tools Validation Criteria

\begin{tabular}{lll}
\hline No. & Average Score & Criteria \\
\hline 1. & $1,00 \leq x<1,75$ & Not Valid \\
2. & $1.75 \leq x<2.50$ & Less Valid \\
3. & $2.50 \leq x<3.25$ & Valid \\
4. & $3.25 \leq x \leq 4.00$ & Very valid \\
\hline
\end{tabular}

$x$ : Validation average score of three validators

Data obtained in implementation stage were observation data of teacher and student activities. Two observers provide observed teacher and student activities. The average observation score of two observers were converted according to Table 3.

Tabel 3

Teacher and Student Activites Observation Criteria

\begin{tabular}{lll}
\hline No. & Average Score & Criteria \\
\hline 1. & $1,00 \leq x<1,75$ & Not Good \\
2. & $1.75 \leq x<2.50$ & Enough Good \\
3. & $2.50 \leq x<3.25$ & Good \\
4. & $3.25 \leq x \leq 4.00$ & Very good \\
\hline
\end{tabular}

Observation average score of two validators

Teaching was said to be effective if (1) students achieved classical mastery learning, (2) the average of creative thinking in class which was taught by problem posing with lesson study approach in digital class setting achieve higher score than taht of mastery learning criteria, (3) the average of creative thinking in the class taught by problem posing with lesson study approach in digital class setting was better than class taught by cooperative teaching model.

Students achieved classical mastery learning if a number of students reach mastery learning score more than $75 \%$ of the total number of students in the class. The test used $\mathrm{z}$ statistic with chance of $\alpha=5 \%$ (Sudjana, 2005). Testing 2 nd criteria using one-sample $\mathrm{t}$ test with 1 tailed and testing 3rd criteria using two-sample t test with 1 tailed.

Descriptive analysis was used to analyze data of mathematical creative process of research subjects. Sugiyono (2010) explains that analyzing qualitative data using three stages of analysis of Miles and Huberman model includes data reduction, data presentation, and conclusion. This technique was used to analyze data of mathematical creative process of research subjects.

\section{Reliability and Validity}

Qualitative data of mathematical creative process of research subjects then are tested for its credibility by using triangulation. Triangulation in the research means checking data from various sources, various methods, or various times. These three techniques were carried out in this study. 
Triangulation of source was done by taking more than 1 research subject at every level of mathematical creative thinking. Triangulation of time was done by observing mathematical creative process on learning process for more than 1 time for every research subjects. Meanwhile, triangulation of methods was done by comparing data of mathematical creative process of research subjects between observation and interview.

\section{FINDINGS AND DISCUSSIONS}

\section{Mathematical Creative Thinking Initial Level}

Initial level of mathematical creative thinking was collected by giving an initial test of mathematical creative thinking in the experimental class. Results of the data collected showed that 4 students on CYL 4, 20 students on CTL 3, 2 students on CTL 2, 6 students on CTL 1, and no students on CTL 0.

\section{Teaching Quality of Problem Posing Model with Lesson Study Approach in Digital Class}

At planning stage, lesson plan made in this research referred to teaching model used. It was problem-posing teaching model. The average of total validation result score of three validators in assessing the lesson plan was 3.47, so it could be stated that the lesson plan was valid. Meanwhile, the test of mathematical creative thinking referred to the indicators of mathematical creative thinking including flexibility, fluency, and novelty. The average of total validation result score of three validators in assessing mathematical creative thinking test was 3.33 , so it could be stated that mathematical creative thinking test was valid.

At the implementation stage, teacher activities during the teaching was in very good criteria. The results of observation showed that the average score of teacher activities on the four meetings given by both observers was 3.41. In addition, the students showed good response to teaching of problem posing with lesson study approach in digital class. The result of the questionnaire showed that the average score of students response to teaching was 3.19. The result study of Gonzalez and Deal (2017) explained that through lesson study, teacher could improve mathematics knowledge in teaching, understand students knowledge, and develop teaching tools based on identifying students level of understanding. These opinion was relevant with the results collected that lesson study could improve teachers abilities during the implementation of teaching.

At evaluation stage, (1) problem posing with lesson study approach in digital class achieve classical mastery learning, (2) the average of creative thinking in class which was taught by problem posing with lesson study approach in digital class setting achieve higher score than that of mastery learning criteria, and (3) the average of creative thinking in the class which was taught by problem posing with lesson study approach in digital class setting was better than class which was taught by cooperative teaching model. Therefore, it can be concluded that problem posing with lesson study approach in digital class setting was effective. The result study of Susanti, Sukestiyarno, Sugiharti (2012) stated that problem posing was effective toward mathematics learning outcomes. Study of Susanti et al. was relevant with the results of this study. However, there are differences of the studied variables. Problem posing collaborated with lesson study 
approach in digital class setting in this research was effective toward mathematical creative thinking.

\section{Mathematical Creative Process}

The data of the results of mathematical creative process based on the creative thinking level at every stage of creative process according to Wallas are as follows.

\section{Mathematical Creative Process at Preparation Stage}

At preparation stage, there is no differences at every mathematical creative thinking level. All research subjects were able to state the core of problem correctly and select relevant informations to solve problems. This is relevant with Siswono's research (2004) which states that in preparation stage, there were no significant differences at every creative group. An example of the work result of S1-A (CTL 1) when working on students worksheets was shown in Figure 1.

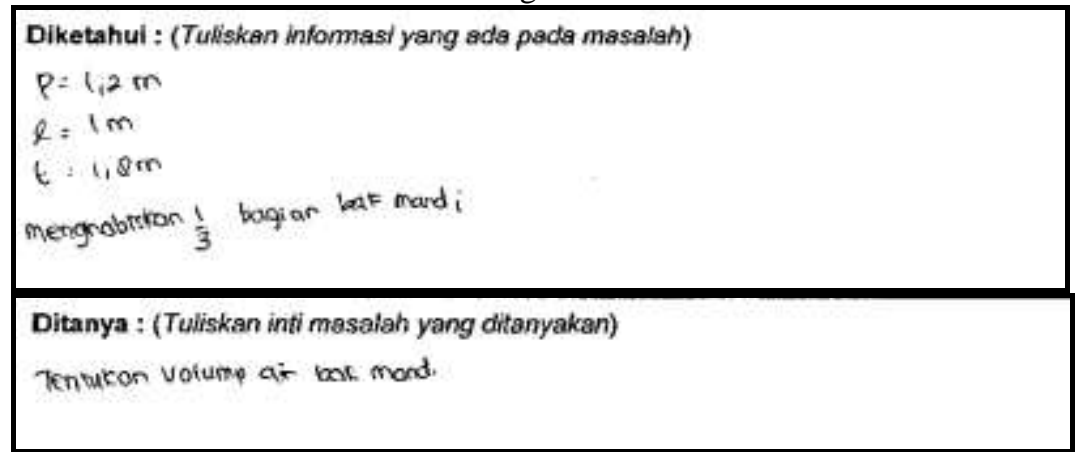

Figure 1

Working Result of S1-A at Preparation Stage

S1-A could state the core of problem correctly and select relevant informations to solve the problem. It was shown with working result of S1-A when stating the information and the core of problem in the box. Having no difference with working result of S4-B (CTL 4), S4-B can also state the core of problem correctly and select the relevant information to solve the problem. This was shown in the working result of S4-B when working on another problem presented in Figure 2.

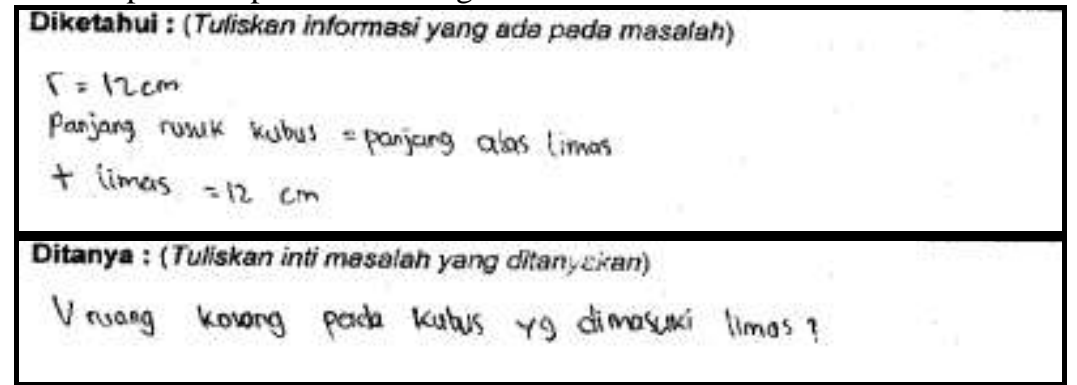

Figure 2

Working Result of S4-B at Preparation Stage 


\section{Mathematical Creative Process at Incubation Stage}

At the incubation stage, all research subjects on CTL 2, CTL 3, and CTL 4 made notes on paper in order to find ideas using trial and error. Meanwhile, research subjects on CTL 1 did not make notes. When studying on the notes of research subjects, two different purposes were found when making notes on paper. First, the research subjects made notes to test their incoming ideas. The ideas became triggering for the emergences of solution. When the research subject guessed the length of edge from volume of a cube, they tried to determine the length of edge by trying a number then powered by 3 then compared with volume of the cube on the problem. The research subject tried several numbers then they are turned into cube number until they had same value to volume of the cube on the problem. This mindset is used by research subjects at every mathematical creative thinking level. It also showed another information that students in junior high school at any level of thinking still had difficulty to guess directly the cubed number. An example of a S3-A notes (CTL 3) in Figure 3 represents the above description.

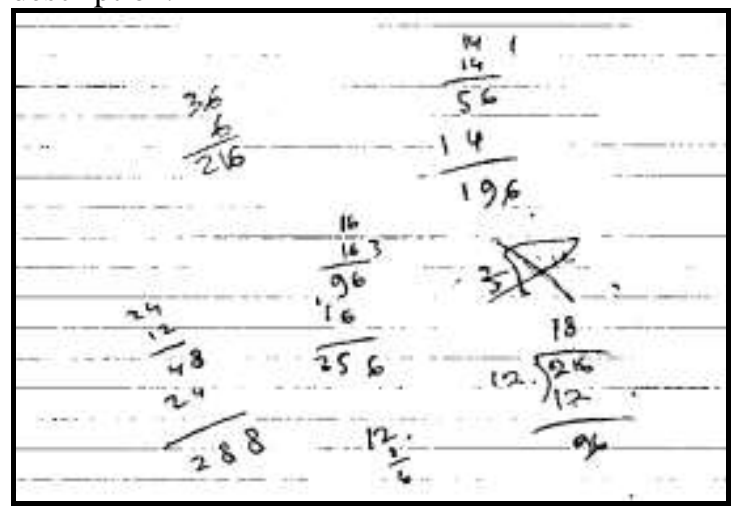

Figure 3

S3-A Notes at Incubation Stage

The second purpose of using notes was to generate another idea after finding previous ideas. This was found in the S3-B notes (CTL 3) during the interview. When S3-B was asked to make any polyhedron with volume $216, \mathrm{~S} 3-\mathrm{B}$ determined the shape first. In case of problems in interview, S3-B made a cuboid. Furthermore, S3-B determined the length and width of the cuboid and ended by calculating the height of the cuboid by dividing the volume on the problem with the length and width of the cuboid. Research subjects still had less practice for determining cube root from number. This was relevant with Orton (2004), when someone was given stimulus about multiplicative operation so he will give quick response by recall his memory about multiplicative product. An example of S3-B notes was shown in Figure 4. 


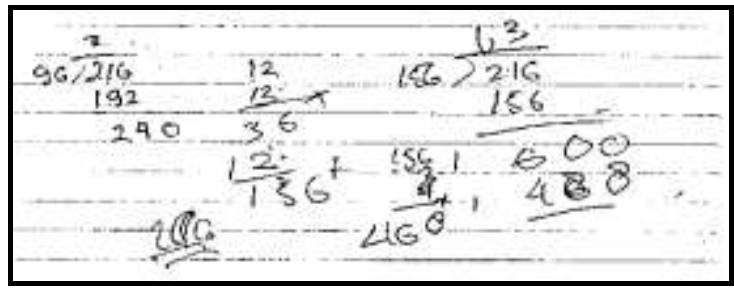

Figure 4

S3-B Notes at Incubation Stage

Another information at incubation stage was that subjects of CTL 2 and CTL 4 move to other problems when they had difficulty. Interview with S2-B (TKBK 2) showed these information.

I : When you have trouble on solving problem, what do you do?

S2-B : I'm looking for an easier problem, I move to it.

Different information shown at research subjects. CTL 1 and TKBK 3 prefer to stay to solve their faced problems. Interviews with S3-A showed these information.

I : When you found trouble, what do you do?

S3-A : $\quad$ I use my logic, I make an example.

I : When you have trouble, do you like to move other problem or stay on your faced problem?

S3-A : $\quad$ Stay on my faced problem.

Q : Why you stay on your faced problem?

S3-A : I want to finish it first.

Research subject on CTL 2 and CTL 4 did not see a problem when looking for an idea for solving problem. Meanwhile, CTL 1 and 3 prefer to read the problem repeatedly and fully when looking for an idea for solving problem. This is contrary to Siswono's research (2004) which stated that all students tend to stop and observe textual and visual information when they were deadlocked in solving problems.

When posing problem, 6 research subjects were able to pose problem well. The six research subjects were the research subjects on CTL 2, CTL 3, and CTL 4. This was very different from research subjects on CTL 1 . Research subjects on CTL 1 are less able to pose problem well. They were less able to divide the main problem into a less simple problems to help solve the main problem. Posed problems of research subjects on CTL 1 was not complete to solve the problem. An example of the result of posed problems of S1-B (CTL 1) is shown in Figure 5.

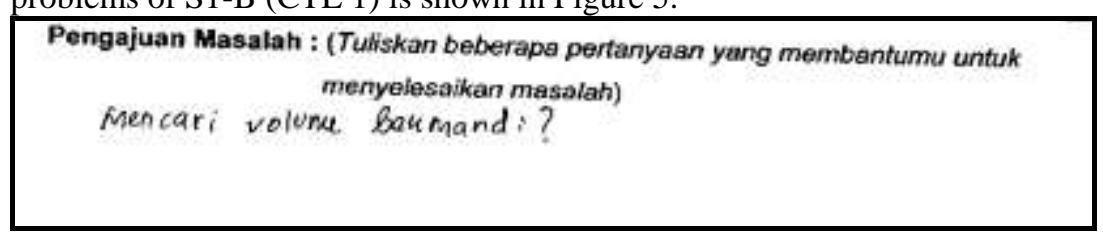

Figure 5

Posed Problems of S1-B at Incubation Stage 


\section{Mathematical Creative Process at Illumination Stage}

At illumination stage, research subject CTL 2, TKBK 3, and CTL 4 were able to solve problems with many ways (flexibility), problems with many solutions (fluency), and problems with unusual solutions (novelty) well. Meanwhile, research subjects on CTL 1 could only solve fluency problem.

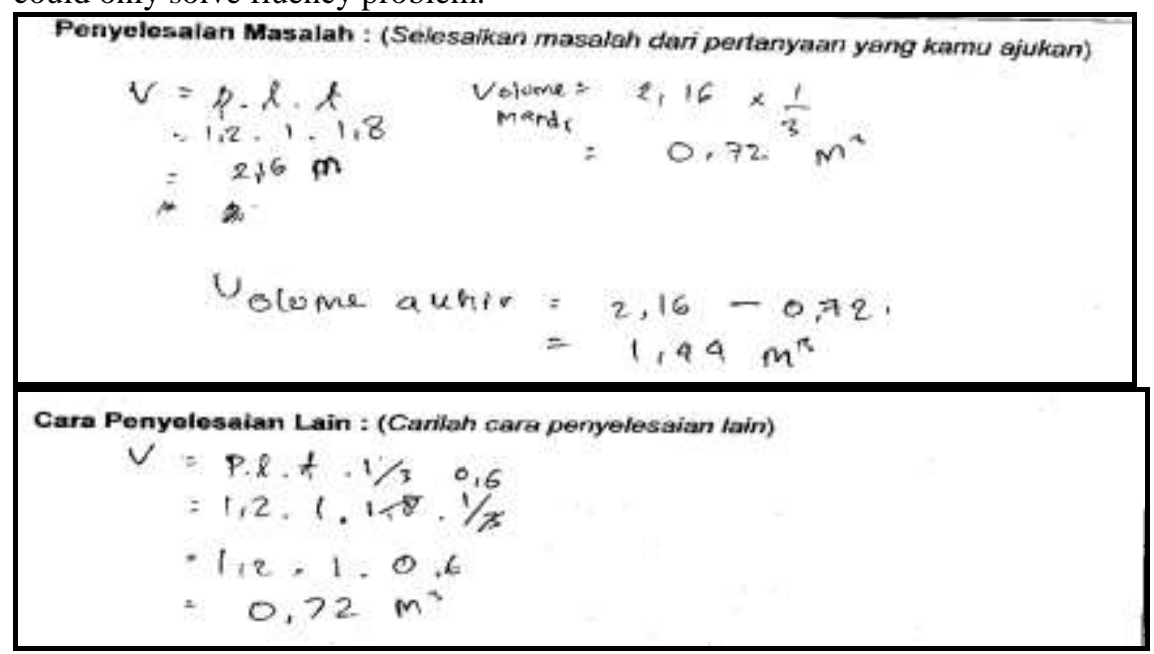

Figure 6

Solution of S1-B at Flexibility Problem

Figure 6 showed that S1-B is not able to solve flexibility problem well. S1-B could not find any idea to solve problem in second way. The second way idea just repeats the first way. This was relevant with Siswono's research (2004) which stated that the more creative groups are able to get the idea and able to solve problem well.

\section{Mathematical Creative Process at Preparation Stage}

At verification stage, there are three different ways of testing solution. First, research subjects check back 2 ways of solving problem whether producing same solutions. Research subjects who had been able to solve flexibility problems would directly check back 2 ways of solving problem whether or not it produced the same solutions. This way was done by research subjects on CTL 2, 3, and 4 .

The second solution test was to test solution by looking back the core of problem and comparing it to solution. This way was done by research subjects on CTL 2 . The last solution test was to check whether there were errors in every step of solving problems. This way was done by all subjects of research. Information of second and third tests are colected just from interviews data on research subjects. During lesson, it was difficult to find these data. Interview with S2-B is presented as follows.

I : When you solve the problem, did you check your answer?

S2-B : First, read the problem again then the answer is checked again and compare it with the problem. The checking is for calculating. 


\section{CONCLUSION}

as follows.

(1) Students' mathematical creative thinking level before the implementation of Problem Posing Model with Lesson Study Approach in the Digital Class is in the range of CTL 1 to CTL 4, they are 4 students on CTL 4, 20 students on CTL 3, 2 students on CTL 2, and 6 students on CTL 1.

(2) Problem Posing Model with Lesson Study Approach in Digital Class had quality to improve creative thinking.

The pattern of students' mathematical creative Wallas Model at (a) preparation stage, all research subjects were able to state the core of problem correctly and select relevant information to solve the problem; (b) incubation stage, different information on each CTL in finding ideas for solving problems, (c) illumination stage, research subjects on CTL 2, CTL 3, and CTL 4 were able to solve flexibility, fluency and novelty problems well while research subjects on CTL 1 solved fluency problems only, and (d) verification stage, there are 3 ways of testing solution done by research subjects, they were checking 2 ways of solving problems whether making the same result, looking back at the core of the problem and comparing it with the solution, and examining whether or not there is an error in every step of problem solving steps.

\section{REFERENCES}

Arnyana, I. B. P. (2006). Pengaruh Penerapan Strategi Pembelajaran Inovatif pada Pelajaran Biologi Terhadap Kemampuan Berpikir Kreatif Siswa SMA. Jurnal Pendidikan dan Pengajaran IKIP Negeri Singaraja 3, Retrieved from http://www.academia.edu/download/40868182/belajar.doc

Astra, M., Umiatin, \& Jannah, M. (2012). Pengaruh Model Pembelajaran Problem Posing Tipe Pre-Solution Posing terhadap Hasil Belajar Fisika dan Karakter Siswa SMA. Jurnal Pendidikan Fisika Indonesia 8, Retrieved from http://journal.unnes.ac.id/nju/ index.php/jpfi/article/ download/2153/2247

Creswell, J. W. (2009). Research Design: Pendekatan Kualitatif, Kuantitatif, dan Mixed. Yogyakarta: Pustaka Pelajar.

Doig, B., \& Groves, S. (2011). Japanese Lesson Study: Teacher Professional Development through Communities of Inquiry. Mathematics Teacher Education and Development 13(1), Retrieved from http://files.eric.ed.gov/fulltext/ EJ960950.pdf

Fernandez, C. (2002). Learning from Japanese Approaches to Professional Development. Journal of Teacher Education 53(5), Retrieved from http://internationalteachercert.wiki.educ.msu.edu/file/view/Japanese $\% 20$ approaches $\% 20$ to $\%$ 20PD\%20(Fernandez).pdf

Gonzalez, G., \& Deal, J. T. (2017). Using a Creativity Framework to Promote Teacher Learning in Lesson Study. Thinking Skills and Creativity, Retrieved from http://www.sciencedirect.com/ science/article/pii/S1871187117301074

Guskey, T. R. (2010). Lesson of Mastery Learning. Educational, School, and Counseling Psychology Faculty Publications 14, Retrieved from http://uknowledge.uky.edu/cgi/viewcontent.cgi? article=1011\&context=edp_facpub 
Khumaidi, M. S., \& Budiarto, M. T. (2013). Jenjang Kreativitas Siswa Dalam Memecahkan masalah Matematika ditinjau dari Kemampuan Matematika Siswa. Jurnal Mahasiswa Teknologi Pendidikan 3(2), Retrieved from http://ejournal.unesa.ac.id/ article/6276/30/article.pdf

Lenski, S. J., \& Caskey, M. M. (2009). Using the Lesson Study Approach to Plan for Student Learning. Middle School Journal 40(3), Retrieved from http://pdxscholar.library.pdx.edu/cgi/ viewcontent.cgi?article=1011\&context=ci_fac

Lestari, K. E. (2015). Penelitian Pendidikan Matematika. Bandung: Revika Aditama.

Mahmudi, A. (2009). Mengembangkan Kompetensi Guru Melalui Lesson Study. Forum Kependidikan 28(2), Retrieved from http://forumkependidikan.unsri.ac.id/userfiles/ Artikel\%20Ali\%20MahmudiUNYOKE.pdf

Orton, A. (2004). Learning Mathematics 3rd Edition. Cornwall: MPG Books Ltd.

Purnomo, A., Kartono, Widowati. (2015). Model Pembelajaran Problem Posing dengan Pendekatan Saintifik Untuk Meningkatkan Kemampuan Pemecahan Masalah. UJMER 4(1), Retrieved from http://journal.unnes.ac.id/sju/index.php/ujmer/article/view/ 6907/4998

Rahmawati, N. T., \& Sugianto. (2016). Analisis Kemampuan Berpikir Kreatif Matematik ditinjau dari Kesadaran Metakognisi Siswa Pada Pembelajaran SSCS berbantuan Schoology. UJMER 5(1), Retrieved from http://journal.unnes.ac.id/sju/index.php/ujmer/ article/view/13613/7224

Silver, E. A. (1997). Fostering Creativity through Instruction Rich in Mathematical Problem Solving and Problem Posing. ZDM 29(3), Retrieved from http://link.springer.com/content/ pdf/10.1007\%2Fs11858-997-0003-x.pdf

Siswono, T. Y. E. (2004). Identifikasi Proses Berpikir Kreatif Siswa dalam Pengajuan Masalah (Problem Posing) Matematika Berpandu dengan Model Wallas dan Creative Problem Solving (CPS). Buletin Pendidikan Matematika 6(2), Retrieved from http://www.academia.edu/ download/31598978/paper04_wallasCPS.pdf

Siswono, T.Y.E. (2010). Leveling Students' Creative Thinking In Solving And Posing Mathematical Problem. IndoMS. J.M.E 1(1), Retrieved from http://ejournal.unsri.ac.id/ index.php/jme/article/viewFile/794/219

Susanti, E. L., Sukestiyarno, YL, \& Sugiharti, E. (2012). Efektivitas Pembelajaran Matematika dengan Metode Problem Posing Berbasis Pendidikan Karakter. Unnes Journal of Mathematics Education 1(1), Retrieved from http://journal.unnes.ac.id/sju/index.php/ujme/article/ download/255/296

Takahashi, A., \& Yoshida, M. (2004). Lesson-Study Communities. Teaching Children Mathematics 10(9), Retrieved from http://bslutrecht.nl/wpcontent/uploads/sites/62/ 2015/11/Takahashi-2004-Ideas-for-establishing-LessonStudy-communities.pdf

Warr, A., \& O’Neill, E. (2005). Understanding Design as a Social Creative Process. Proceedings of The 5th Conference on Creativity \& Cognition, Retrieved from https://www.researchgate.net/profile/Eamonn_ONeill/publication/221629731_Understandin g_Design_as_a_Social_Creative_Process/links/02bfe5141ff3cb3754000000.pdf

Zevenbergen, R., Dole, S., \& Wright, R. J. (2004). Teaching mathematics in Primary Schools. Crows Nest, NSW: Allen \& Unwin. 